\title{
Ayurveda Internal Medicine for the Management of Common Metabolic Disorders W.S.R. to Madhumeha and Sthoulya
}

\section{Dr. Dhananjay S. Khot}

MD (Ayu), Dept. Kayachikitsa, Rural Institute of Ayurved Research Center \& Hospital Vidyagiri, Vita Road, Mayani, Tal.- Khatav, Dist.- Satara, Maharashtra, India.

\section{ABSTRACT}

The metabolic disorders are major health issues of today's scenario and incidences of metabolic diseases increases day by day due to the disturbed pattern of life style. Ayurveda texts have described term "Santarpanjanya Vikaras" which resembles diseases of defective tissue metabolism. Ayurveda mentioned that improper dietary habits and sedentary life style affects state of Agni which resulted Ama production and finally leading to the metabolic syndrome. The vitiation of Dosha, diminish state of Dhatu and blockage of channels, etc. also can initiate pathogenesis of metabolic disorders. The Kayachikitsa branch of Ayurveda recommended use of internal medicine for the management of various metabolic disorders. Considering increased health burden of society due to the metabolic syndrome present article explore role of ayurveda internal medicine for the management of metabolic syndrome.
\end{abstract}

Keywords: Ayurveda, metabolic syndrome, Santarpanjanya, Madhumeha and Sthoulya.

Article Info: Received 08 July 2019; Review Completed 24 Aug 2019; Accepted 29 Aug 2019; Available online 15 Oct 2019

\section{Cite this article as:}

Khot DS, Ayurveda Internal Medicine for the Management of Common Metabolic Disorders W.S.R. to Madhumeha and Sthoulya, Journal of Drug Delivery and Therapeutics. 2019; 9 (5-s):1647169 http://dx.doi.org/10.22270/jddt.v9i5-s.3637

\section{*Address for Correspondence:}

Dr. Dhananjay S. Khot, MD (Ayu), Dept. Kayachikitsa, Rural Institute of Ayurved Research Center \& Hospital Vidyagiri, Vita Road, Mayani, Tal.- Khatav, Dist.- Satara, Maharashtra, India.

\section{INTRODUCTION}

The metabolic disorders are considered as one of the major health issues now a days and prevalence of such diseases increases day by day due to the disturbed pattern of daily regimen. Sthaulya/Medoroga, Prameha and Hridroga are major metabolic disorders affecting population globally. The vitiation of Medadhatu, Medodhatvagni and Rakta can initiate pathogenesis of metabolic disorders. The indigested food sometimes forms Ama and when this Ama interacts with Medadhatu then Sama Medadhatu (unhealthy lipids) formed. The Ama when circulates throughout the body then it block microchannels and affects normal circulatory process thus triggers pathogenesis of metabolic disorders [1-4].

Ayurveda described that Snigdha, Pichhila and Guru Ahara Sevana, Madyapana and Atiasan behavior, etc. can causes metabolic disorders, the other causative factors depicted in Figure 1.

Vitiation of Kapha plays a significant role towards the accumulation of Amadosa which can leads disorders such as; dyslipidemia, obesity and hyperglycemia etc.
Vitiation of Pitta can leads Medovridhi associated with Srotosanga, Vata \& Vata vitiation can create state of Avrita Vata.

The production of abnormal Medadhatu exceeded in metabolic disorders but its utilization suppresses resulting deposition of fat inside the body (atherosclerotic). The hormonal imbalance like can also cause diseases like; hyperglycemia and hyperthyroidism or hypothyroidism. Ayurveda mentioned that Dusya in Rasa, Meda and Mamsa can trigger pathogenesis of metabolic disorders.

The involvement of Srotasa in metabolic syndrome can't be ignored; it is believed that Srotasadusti in Raktavaha, Rasavaha, Medovaha and Mamsavaha Srotasa plays an important role towards the pathogenesis of metabolic disorders.

The metabolic disorders can be elaborated as Santarpana Janya Vyadhi since it involves vitiation of Agni, production of Ama, vitiation of Kapha and Meda etc. The major diseases comes under category of metabolic disorders are Madhumeha (diabetes mellitus), Ati Sthoulya (obesity), Srotsam Lepa (artherosclerosis), Dhamani pralepa (arterial disorders) and dyslipidemia. Ayurveda described various 
approaches for the management of such problems including; conduction of healthy daily regimen, exercise, meditation, avoidance of stress and use of herbal medicine, etc. The use of internal medicine obtained from natural sources play key role in the management of metabolic disorders, considering this fact present article emphasizes role of internal medicine in metabolic disorders [2-5].

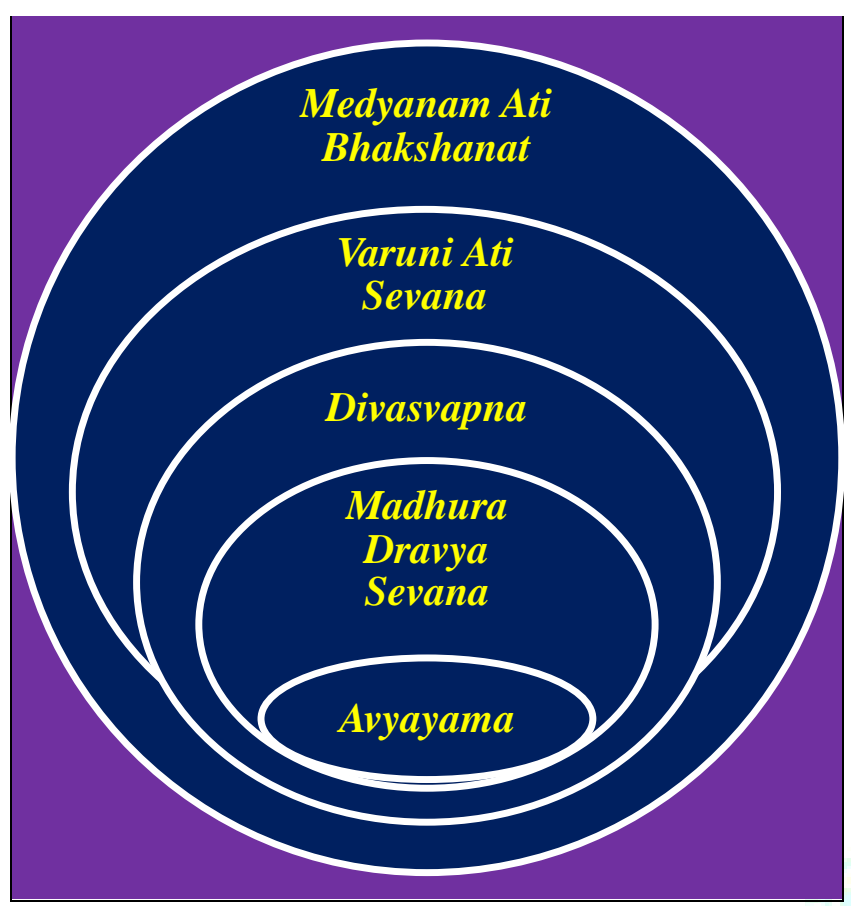

\section{AYURVEDA MANAGEMENT OF METABOLIC SYNDROME:}

The basic principles of treating metabolic syndrome as per Ayurveda involve use of drugs which alleviates Vata, reduces Kapha and help to regularizes circulatory and hormonal functional of body. The drug which metabolizes excessive fat and improves digestive fire also offers beneficial effects in case of metabolic disorders. Ayurveda recommended Aptarpana, Vanaspati Kashaya, Lekhana Kashaya and Kaphahara Chikitsa for the management of metabolic disorders especially related to the excess deposition of fat. The Table 1 showed various herbs and formulations used for the management of metabolic disorders [6-10].

Table 1: Herbs and formulations used for the management of metabolic disorders:

\begin{tabular}{|l|l|}
\multicolumn{1}{|c|}{$\begin{array}{c}\text { Compound } \\
\text { formulations }\end{array}$} & \multicolumn{1}{c|}{ Herbs } \\
\hline Medohara guggulu & Vrikshamla (Garcinia indica) \\
\hline Nisamlaki Churna & Guggulu (Commiphora mukul) \\
\hline Punarnavadi guggulu & $\begin{array}{l}\text { Meshshringi (Gymnema } \\
\text { sylvestre) }\end{array}$ \\
\hline Sapragandha ghanavati & Rasona (Allium sativum) \\
\hline Puskarabramhi guggulu & Puukaramula (Inula racemosa) \\
\hline Triphaladi guggulu & Arjuna (Terminalia arjuna) \\
\hline Amritadi guggulu & Haridra (Curcuma longa) \\
\hline
\end{tabular}

The specific therapeutic benefits of various ayurveda medicines in metabolic disorders depicted in Table 2.

Figure 1: Causative factors of metabolic syndrome as per ayurveda.

Table 2: Drugs and their role in metabolic disorders:

\begin{tabular}{|c|c|c|}
\hline S. No. & Ayurveda Drugs & $\begin{array}{c}\text { Therapeutic benefits in metabolic } \\
\text { disorders }\end{array}$ \\
\hline 1 & Trikatu Churna, Chitrakadi Vati and Pippali Churna & Promote Agni and correct metabolic process. \\
\hline 2 & Amalaki, Guduci, Silajatu and Haridra etc. & Promote Ojas (immunity enhancer). \\
\hline 3 & Guduchi, Triphla, Musta and honey, etc. & Helps to remove excessive fat. \\
\hline 4 & Shunthi, Vidanga, Yavaksara, barley powder and Amalaka & $\begin{array}{l}\text { Offers beneficial effects in management of } \\
\text { obesity and corrects digestive fire. }\end{array}$ \\
\hline 5 & Dasamoolarishta & Helps in jaundice and Prameha. \\
\hline 6 & Kaisora Guggul & Useful in diabetes. \\
\hline
\end{tabular}

\section{AYURVEDA MEDICINE FOR MADHUMEHA:}

Diabetes is a condition in which body fails to metabolize carbohydrate properly or sugar level increases. Ayurveda herbs offers several health benefits in diabetes such as; suppression of root cause of disease, strengthening immunity, enhances digestion, regularizes hormonal level and boosts overall circulatory process. Jamuna (Syzygium Cumini), Daruharidra (Berberis lyceum), Gudmaar (Gymnema Sylvestre), Karela (Momordica Charantia) and Haridra (Curcuma Longa), etc. can be used as a natural drugs in case of diabetes.

\section{Jamuna (Syzygium Cumini)}

The seeds of Jamuna (Syzygium Cumini) offer health benefits in diabetes especially seeds of plant. Ayurveda also mentioned Jamuna as digestive ailments; the Jamun seeds contain substance called Jamboline which suppress release of sugar into blood stream.

\section{Daruharidra (Berberis lyceum)}

Daruharidra is a common ayurveda drug used for diabetes, its root produces berberine which relief symptoms of diabetes. The symptoms of related to skin and eye of diabetes improved by root of Berberis lyceum. It improves parameters like body weight, amount of urine and lowers down the fasting blood glucose levels. 


\section{Gudmaar (Gymnema Sylvestre)}

Gudmaar suppress sweetness due to the presence of active components named gymnemic acid, it make sweet foods less appealing thus prevent desire to consume sweet food. It can be used in combination with other medicine to lower down blood sugar level.

\section{Karela (Momordica Charantia)}

Karela is commonly used as vegetable but it persists medicinal properties and offers therapeutic benefits in the management of diabetes. It contains hypoglycemic compound which helps to lower down sugar levels in blood. The charantin is one of the chief components found in Karela which offers blood glucose lowering effect. Another compound polypeptide-p also control diabetes naturally.

\section{Haridra (Curcuma Longa)}

Turmeric rhizomatous can be used for the treatment of diabetes; it contains curcumin which reduces glycemia and hyperlipidemia. It balances overall blood sugar levels, reduces fat and cure symptoms of diabetes.

\section{AYURVEDA MEDICINE FOR STHAULYA/MEDOROGA}

Obesity is one of the common metabolic disorders mainly occurs due to the bad conduction of daily regimen and disturbed dietary pattern. Ayurveda described various herbs for the management of obesity including; Triphala, Guggul, Kalonji, Punarnava, Aloe vera and Pepper, etc. Shyamaka, Yavaka, Kulatha, Makustha and Patola types of fruits can be used for obesity.

\section{Triphala}

Triphala is a poly-herbal formulation containing Amalaki, Bibhitaki and Haritaki, it reduces weight and metabolizes excess fat from body and regularizes digestive and circulatory functions thus relief various metabolic disorders.

\section{Guggul}

Guggul is a dried resin used mainly for weight loss purpose. It breaks fat cells, regulates hormonal balances and control metabolic activities of body thus help in obesity. It reduces deposited fat and along with other medicine it control obesity associated with diabetes.

\section{Kalonji}

Kalonji known as black cumin, the seeds and oils of seeds offers weight loss properties thus help in case of obesity.

\section{Vijaysar}

It offers anti-hyperlipdemic properties, reduces total cholesterol, low-density lipo-protein and also controls serum triglyceride levels thus help to treat obesity. It relief symptoms of metabolic diseases like; frequent urination, overeating and numbness. Vijaysar also help to treat obesity associated with diabetes.

\section{CONCLUSION}

The metabolic disorders has now becomes major health issues in current scenario and incidences of such cases increasing day by day due to the disturbed pattern of daily regimen. Ayurveda mentioned that improper functioning of Agni, production of Ama, vitiation of Dosha \& Dhatu and blockage of channels, etc. can leads metabolic disorders. Madhumeha, Ati Sthoulya, Srotsam Lepa, Dhamani pralepa and dyslipidemia etc. are diseases which can be considered as metabolic disorders. The branch of Ayurveda; Kayachikitsa recommended use of internal medicine for the management of various metabolic disorders along with conduction of healthy daily regimen, meditation, exercise and Yoga etc. Herbs like; Vrikshamla Guggulu, Meshshringi, Rasona, Puukaramula, Arjuna and Haridra, etc. can be used for the along with formulations such as; Medohara guggulu, Nisamlaki Churna, Punarnavadi guggulu, Sapragandha ghanavati, Puskarabramhi guggulu, Triphaladi guggulu and Amritadi guggulu, etc. These all drugs obtained from natural origin and offer several health benefits in the management of metabolic disorders. The Aptarpana, Vanaspati Kashaya, Lekhana Kashaya, Kaphahara and Vatahara effects of these internal medicine helps to break pathogenesis of metabolic disorders and can be used as alternative therapy for the management of diseases like; Madhumeha, Ati Sthoulya and Dhamani pralepa, etc.

\section{REFERENCES}

1. Gaddam K.K, Ventura H.O, Lavie C.J "Metabolic syndrome and heart failure" the risk, paradox, and treatment. Current Hypertension Rep. 2011:13:142-8.

2. Reaven G.M and Banting L "Role of insulin resistance in human disease" Diabetes 1988; 37:1595-1607.

3. Chakradutta. Chakrapanidutta, Vaidyprabha Hindi Commentary by Tripathi, Indradev Chaukhabha Sanskrit Sansthan Varanasi. 1997.

4. Madhav Nidan, Shastri Sudarsana, Vidyotini Hindi Commentory, Chaukhambha Sanskrit Sansthan Varanasi. 2006.

5. Kaur J (2014). "A comprehensive review on metabolic syndrome". Cardiology Research and Practice, 2014: 943162. doi:10.1155/2014/943162.PMC 396 6331. PMID 24711954.

6. Agnivesh, Charaka, Dridhbala, Charaka Samhita, Sutrasthan, 17/80. English Translation by Sharma RK and Bhagwan Dash. Vol. 4. Reprint. Chowkhamba Sanskrit Series Office, Varanasi, 2009.

7. Agnivesh, Charaka, Dridhbala, Charaka Samhita Chikitsasthan, 28/238-240. English Translation by Sharma RK and Bhagwan Dash. Vol. 4. Reprint. Chowkhamba Sanskrit Series Office, Varanasi, 2009.

8. Charaka samhita, Sootra sthana, Chaukhamba publication, Reprint edition - 2011 23rd chapter, verse 03-07, pg no - 122, pp- 738.

9. Shushruta samhita, Sootra sthana, Chaukhamba publication, Reprint edition - 2011 15th chapter, verse 32, pg no - 73pp824.

10. Acharya YT (2009). Sushrutha Samhita with Nibandhasangraha commentary of Dalhana: Chowkambha Orientalia, Varanasi, Reprint ed. 2,106,148, 255. 